\title{
Forensic Accountants: Financial Investigators
}

Les Nunn, (Email: lnunn@usi.edu),University of Southern Indiana Brian L. McGuire, (Email: bmcguire@usi.edu),University of Southern Indiana Carrie Whitcomb, University of Southern Indiana

Eric Jost, University of Southern Indiana

\begin{abstract}
The public fraud scandals with companies like Enron and WorldCom, the Internet and other technological advances, and even the threat of terrorists have created a large demand for the skills and services provided by forensic accountants. Forensic accountants are in high demand because they play a critical role in an investigation of suspected financial scandals and misappropriation of assets. It is their job to bring independence and credibility to these investigations.
\end{abstract}

\section{INTRODUCTION}

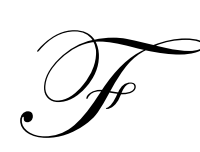

orensic accounting is a method of investigating financial transactions and business situations in order to obtain the truth of and develop an expert opinion regarding possible fraudulent activity. Two areas of expertise make up the field of forensic accounting: litigation support, and investigative or fraud accounting. Litigation support includes business valuation, revenue analysis, expert witness testimony, and future earnings evaluation. Investigative accounting is the process of gathering evidence of criminal conduct, and substantiating or disproving damages (Fillmer, 2003).

Not a new profession, forensic accounting has been around for several decades; however, the recent wave of corporate scandals, new accounting rules, and the Sarbanes-Oxley Act are forcing companies to search more aggressively for fraud. Forensic accountants are now being hired by boards of directors to assist with companies' corporate governance and financial reporting, in efforts to reduce fraud (Iwata, 2003).

\section{HISTORY OF FORENSIC ACCOUNTING}

The earliest know evidence of forensic accounting has been traced to an advertisement in a newspaper in Glasgow, Scotland, appearing in 1824. At that time, arbiters, courts, and counsels, used forensic accountants to investigate fraudulent activity. However, it was not until the early 1900s in the United States and England, when articles providing guidance on giving expert testimony appeared (Crumbley, 2003).

Need for forensic accounting has resulted from regulatory and criminal statutes passed over time. In the early 1900s, the adoption of the Federal Income Tax created demand for forensic accountants, due to income tax evasion. As a result, the Internal Revenue Service (IRS) developed many of the forensic techniques used to detect tax evaders. One of the first income tax evasion cases uncovered by forensic accountants was that of the infamous gangster, Al Capone. During World War II, the Federal Bureau of Investigation (FBI) employed over 500 forensic accountants who were used to examine and monitor financial transactions (Ziegenfuss, 2003).

As the forensic accounting profession has grown over time, several publications have been produced to provide guidance. In 1946, Maurice Peloubet, an accountant from New York, published the article entitled "Forensic Accounting: Its Place in Today's Economy." The book, Forensic Accounting: The Accountant as an Expert Witness, was written by Francis C. Dykeman, in 1982. The American Institute of Certified Public Accountants (AICPA) issued Practice Aid 7 in 1986, which outlines six areas of litigation services including: damages, antitrust, accounting, 
valuation, general consulting, and analyses. Also among the literature featuring forensic accounting, is the Journal of Forensic Accounting: Auditing, Fraud \& Taxation. Due to the growth of the profession, the American Board of Forensic Accountants was founded in March of 1997. Currently, there are at least sixteen universities and colleges offering courses in forensic accounting (Crumbley, 2003).

\section{CHARACTERISTICS OF FORENSIC ACCOUNTANTS}

There is a definite need for forensic accountants in the business world today, but not everyone possesses the many characteristics and qualities that comprise a high quality forensic accountant. Forensic accountants need to possess strong written and oral communication skills. In this profession it is imperative to have a strong accounting background; a thorough knowledge of auditing, risk assessment, and control and fraud detection; and a basic understanding of the legal system. It is important for forensic accountants to possess the ability to interview and effectively elicit information from people who may not be willing to give truthful answers. Therefore, it is important for forensic accountants to be skeptical of those people that they deal with. Knowledge and experience in financial planning and management techniques, as well as advanced computer skills, including an ability to understand and apply various information technology and accounting systems, are also key characteristics of forensic accountants (Crumbley, 2003).

There are many skills and characteristics that are necessary for successful forensic accountants. Effective forensic accounting requires:

- $\quad$ Education and training,

- $\quad$ Advanced and continued education in appropriate disciplines,

- $\quad$ Diversified accounting and auditing experience,

- Communication skills - oral and written,

- $\quad$ Practical business experience,

- $\quad$ Diversified forensic auditing experience,

- $\quad$ Ability to work in a team environment, and

- $\quad$ People skills and flexibility (Grippo, 2003).

However, the most important skill is experience. This experience is gained through natural maturing in the profession. In experience, the forensic accountant acquires skills in accounting and auditing, taxation, business operations and management, internal controls, interpersonal relationships, communication, and people. Knowing how a business operates and effective types of internal controls is a critical part of being a forensic accountant (Grippo, 2003). It is also recommended that an accountant that wants to become a fraud expert should go work for a law enforcement agency. The experience of working on complex fraud cases in law enforcement for several years offers invaluable knowledge (Wells, 2003).

\section{DIFFERENCES BETWEEN INDEPENDENT AUDITOR AND FORENSIC ACCOUNTANT}

An auditor essentially intends to uncover significant deviations from generally accepted accounting principles (GAAP) and to verify that acceptable accounting and auditing practices have been used in the preparation of the financial statements. The forensic accountant takes a much more skeptical and proactive approach to uncovering fraud, not just verifying what is in the financial statements (Crumbley \& Apostolou, 2002).

The difference between the independent auditor and forensic accountant relies mainly in their objectives. The independent auditor generally assumes that the client has conformed to GAAP. The independent auditor also follows the guidelines set forth by the generally accepted auditing standards (GAAS). After the audit, they can recommend adjustments to enhance the fairness of the financial reporting (Conway \& Rouse, 2002).

On the other hand, forensic accountants make no assumptions. The forensic accountant critically assesses the legitimacy of the company's financial transactions and conformity to GAAP. When there is alleged fraud, it is 
important to engage independent forensic accountants because the current auditors may encounter potential inherent conflicts (Conway \& Rouse, 2002).

\section{SERVICES PROVIDED BY FORENSIC ACCOUNTANTS}

Forensic accounting consists of a broad area of financial statement investigation and litigation support. Various positions including consultants, internal auditors, bankruptcy specialists, bank examiners, and valuators of closely held businesses, as well as lawyers and professors, can be held by forensic accountants. Among the many services offered by forensic accountants are: litigation support, expert witness engagements, divorce business valuation, and lost earnings engagements.

\section{Litigation Support}

Litigation support consulting is a service where forensic accountants provide an opinion based on known facts or facts that are yet to be uncovered. When the facts are unknown, the forensic accountants investigate the situation and then form an opinion based on their investigative work. Litigation support services include engagements concerning professional liability claims and civil claims. Professional liability claims consulting includes quantifying the loss from events of insurance disputes, delayed construction, and stolen trade secrets. Civil claims consulting examples include business valuations, employee theft, and investigating accidents (Fillmer, 2003).

\section{Expert Witness Engagements}

Forensic accountants may serve as expert witnesses in litigation cases involving the area of accounting. The forensic accountants may be asked to prepare a tax analysis, perform economic fact-finding, suggest interrogation questions, or help interpret documentation. The accountants may or may not be required to testify as an expert witness in a courtroom. Serving as an expert witness is quite important and challenging. The forensic accountants must keep in mind the judge and jury may not be familiar with accounting jargon. Thus, the accountant should explain everything thoroughly and avoid being too complex. As an expert witness, the accountant must perform all investigative work himself because he will be the one answering in the court. Inability to answer a question on the witness stand can damage forensic accountants' professional reputation and future careers (Fillmer, 2003).

\section{Divorce Business Valuations}

Forensic accountants are frequently called upon to resolve divorce settlements between spouses who have ownership in a private company, partnership, or business. It is the forensic accountant's job to evaluate the business and determine an appropriate financial breakdown of the assets. The accountant's objective in settling a divorce business valuation is to establish a realistic value of the business consistent with the client's goal, a value defendable under cross-examination in the courtroom. Information available to the accountants may be limited and some information may even be a misrepresentation of the financial situation. Thus, it is important that the forensic accountants conduct a deep investigation, and look beyond the balance sheets and statements of earnings.

When analyzing the balance sheets, the investigator must be concerned about hidden assets and liabilities. Examples of a hidden assets and liabilities are: fully depreciated equipment, ownership of franchise and royalty rights, misstated inventories, the cash surrender value of life insurance policies, unrecorded leases, and under-funded pension liabilities. Any and all adjustments made to the balance sheets should be of concern to the forensic accountants. Such balance sheet adjustments may include adjusting investments to the lower of cost or market, LIFO reserve adjustments, and amortization methods.

The forensic accountant should be looking for hidden or unrecorded earnings and possible overstated expenses when analyzing the statement of earnings. Unrecorded cash receipts are an example of unrecorded earnings. Examples of unrecorded expenses include overstated travel expenses, entertainment, and utilities. The statement of earnings must also be analyzed for any adjusting entries such as: adjustments to top executive salaries or bonuses, lease expenses to a related party, and interest on related party debts. 
As with every forensic investigation, the accountants must question all information that is presented. The goal of the investigation is to determine a fair and unbiased financial evaluation of the business. Once forensic accountants analyze the business and form an opinion, it is necessary to assist the litigating attorney in defending this opinion in the courtroom as expert witnesses (Fillmer, 2003).

\section{Lost Earnings Engagements}

Litigation support provided by forensic accountants also includes investigating lost earnings cases. Lost earnings are the monies the plaintiff would have made had it not been for the actions of the defendant. Examples of lost earnings cases include damage or loss estimates, personal injury, and wrongful death.

Forensic accountants gather and analyze information to determine lost earnings and then form an opinion based on their in-depth analysis. During the investigative process accountants must make judgment calls such as weighing his obligation to the client with the standards established in the profession. The forensic accountants must keep in mind that he is being paid to develop an opinion based on their investigations.

Forensic accountants follow a five-step process to estimate the value of lost earnings. First, they must identify the amount to be used as the base earnings. Next, they must determine a damage period and identify an appropriate rate of growth. Adjustments must then be made for mitigating circumstances. Finally, forensic accountants will choose an appropriate discounting technique.

In order to identify the base earning the accountants must identify the amount of revenue being received prior to the incident that caused the earnings to cease or decline. The forensic investigators should examine revenue from normal business operations as well as revenue from special projects. The growth rate is the expected percentage rate increase of earnings during the damage period, and it is based on the base earnings and the damage period. Industry standards and historical data are also consulted to determine the growth rate. The accountants then identify mitigating circumstances, which offset the monetary value of damage suffered. Mitigating conditions include the effect of income taxes and the effect of consumption of resources. Forensic accountants have six different discounting methods to choose from including: traditional discounting, inflate discounting, partial offset discounting, total offset discounting, Supreme Court discounting, as well as trial and error discounting. Future earnings are quantified and then discounted to present value based on the discounting method chosen (Fillmer, 2003).

\section{NEW REGULATIONS}

One reason for the increased demand for forensic accountants is the post-Enron era. New accounting rules, SAS 99, and the Sarbanes-Oxley corporate reform law are a direct result of the Enron scandal and many others. Because of these new laws and regulations, nervous executives have been hiring hundreds of forensic accountants, investigators, and attorneys from law enforcement and government agencies, including the FBI, the SEC, and the IRS (Iwata, 2003).

The American Institute of Certified Public Accountants (AICPA) has issued a new standard in response to the recent barrage of scandals. SAS 99, according to Joseph Wells, is unique because it claims that there is a risk of fraud in every business. The new standard describes specific steps that the auditors must follow during an audit engagement. These steps include pre-audit brainstorming, increased professional skepticism, additional inquiries, consideration of risk factors, a determination of the response to the risk factors, and extensive documentation. SAS 99 also requires that the audit staff be evaluated to determine if they have enough fraud expertise (Wolosky, 2004).

In 2001, President Bush signed into law an anti-terrorism bill, known as the Patriot Act, containing major money-laundering changes. The law requires banks and brokerages to screen new accounts for any taint of terrorist assets. Financial institutions must check accounts against the list of terrorists designated by the Treasury Department's Office of Foreign Asset Control. This new law has increased the demand for forensic accountants because of the skills and expertise required to track assets (Arvedlund, 2001). 


\section{NEW TECHNOLOGY}

Most of the criminals behind fraud use sophisticated technology and accounting tricks to commit complex frauds. This means that the forensic accountants need state-of-the-art facilities to uncover fraud. Deloitte \& Touché has set up a worldwide network of computer forensic labs for their forensic accountants and technicians (Iwata, 2003).

Computers are common tools used by the culprits behind white-collar crimes. In order to find "the smoking gun," the forensic accountant will need to be able to dig deep into the company's computer system. However, without the proper equipment, that process can prove to be very difficult. To facilitate the preservation, collection, analysis, and documentation of evidence, forensic accountants can use specialized software and computer hardware. There are many new technologies that allow the investigators to recover deleted files, crack encryptions or codes, and extract and sort data (Bigler, 2001).

KPMG Forensic Accounting has developed software that it uses to aid in determining how the fraud was perpetrated. The software prepares a TRACE (Transactional Representation of Assets and Court Evidence) diagram. The TRACE diagram provides a computer-generated graphical and concise summary of a series of transactions, events or structures in an easy-to-read format, to map the flow of funds through the perpetrator's private companies/accounts, identify the parties involved, and provide litigation support to the civil and criminal proceedings (Sing, 1999).

A software program (called Gargoyle) can detect steganography (i.e., steganography is a process by which data can be hidden within other files). Using steganography, a fraudster could hide stolen data within an MP3-format song making it virtually undetectable until Gargoyle. WetStone Technologies released the Gargoyle software in May 2003. It was developed to work with the government-sponsored National Software Reference Library (NSRL) database. The NSRL database is a collection of digital file signatures, known as hashes, developed from thousands of common software programs. These hashes allow investigators to check if any alterations have occurred. Currently, Gargoyle can identify a large quantity of programs. In addition to stenography programs, Gargoyle includes 550 Trojan-horse toolkits, 94 wireless-war-driving software tools, 455 file encryption programs, and hundreds of keylogging and password-cracking applications (Piazza, 2003).

A company based out of Houston (called ChurchStreet Technology) has developed a very useful tool for forensic accountants and other crime-fighting agencies. ChurchStreet has developed a method for reconstructing shredded documents electronically, offering a speedier alternative to the laborious task of searching, matching, and pasting strips manually. The process uses proprietary digitizing techniques to scan the shredded paper and then matches them with specialized software. The software can even reconstruct documents that have been cross-shred or cut in two directions into tiny pieces (Satov, 2003).

\section{SUMMARY AND CONCLUSION}

The public fraud scandals with companies like Enron and WorldCom, the Internet and other technological advances, and even the threat of terrorists have created a large demand for the skills and services provided by forensic accountants. Forensic accountants are in high demand because they play a critical role in an investigation of suspected financial scandals and misappropriation of assets. It is their job to bring independence and credibility to these investigations.

Forensic accountants need many skills to perform their specialized jobs. Education and training in accounting and business as well as communication skills are necessary. The most important skill is experience. This experience is gained through simply maturing in the profession. In experience, the forensic accountant acquires skills in accounting and auditing, taxation, business operations and management, internal controls, interpersonal relationships, communication, and people. The experience of working on complex fraud cases in law enforcement for several years offers invaluable knowledge. 
There have also been a number of new laws and regulations affecting the need for forensic accountants and

how they perform. For example, two of these laws are the Sarbanes-Oxley Act and the Patriot Act, and one of the regulations affecting them is SAS 99.

Forensic accountants must be as good with people as they are with numbers. They should also be inclined to be aggressive rather than timid and shy. These characteristics allow them to be successful in adversarial situations where confrontation is mandatory to their work (Wells, 2003).

\section{REFERENCES}

1. Arvedlund, Erin E. How Wall Street, Money Men Help Catch the Bad Guys. Barron's, 19 November 2001, p 11.

2. $\quad$ Bigler, Mark. Computer Forensics Gear. The Internal Auditor, August 2001, p 27.

3. Conway, A. Carr and Robert W. Rouse. This is a Job for Superman: Calling in a Forensic Accountant. The Journal of Corporate Accounting \& Finance, May/June 2002, p 23.

4. Crumbley, D. Larry. Certified Forensic Accountant. American College of Forensic Examiners International, 20 May 2003, online posting.

5. Crumbley, D. Larry and Nicholas Apostolou. Forensic Accounting: A New Growth Area in Accounting. Ohio CPA Journal, July/September 2002, p 16.

6. Fillmer, Scott. Forensic Accounting Defined. www.cris.com/ dfillmer/forensic.htm, 27 MY 2003, online posting.

7. Grippo, Frank. Introduction to Forensic Accounting. The National Public Accountant, June 2003, p 4.

8. Iwata, Edward. Accounting Detectives in Demand. USA Today, 27 February 2003.

9. $\quad$ Piazza, Peter. Now You See It. Security Management, December 2003, p 26.

10. Satov, Tamar. Back from the Shred. CA Magazine, November 2003, p 10.

11. Sing, Alan. Forensic Accounting: Looking for Clues. Australian CPA, March 1999, p 42.

12. Wells, Joseph T. The Fraud Examiners. Journal of Accountancy, October 2003, p 76.

13. Wolosky, Howard W. Forensic Accounting to the Forefront. The Practical Accountant, February 2004, p 22.

14. Ziegenfuss, Douglas. Forensic Accountants: Hot Old Profession. www.odu.edu/ao/instadv/quest/ ForensicAccount.html, 25 May 2003, online posting. 